\title{
MUROID RODENTS OF THE LOWLAND PART OF TRANSCARPATHIA: STATE OF POPULATIONS AND MORPHOPHYSIOLOGY
}

\author{
Zoltan Barkasi \\ National Museum of Natural History, NAS of Ukraine \\ Bohdan Khmelnytsky St. 15, Kyiv, 01601 Ukraine \\ E-mail: zlbarkasi@ukr.net
}

\begin{abstract}
Muroid Rodents of the Lowland Part of Transcarpathia: State of Populations and Morphophysiology. Barkasi, Z. - The present paper deals with the results of investigation of muroid rodent populations inhabiting on the Transcarpathian lowland. The field works to collect materials were held in three types of biotopes within the Berehove raion. The paper contains information on the most common species of muroid rodents within the studied area, which is a typical lowland region of Transcarpathia. The relative abundance and tendencies in the sex and age structure of populations are analyzed. The lengths of the body, tail, foot and auricle were measured to investigate the age- and sex-related variability of morphological features. The relative weight of physiologically important organs such as heart, liver, kidneys and adrenal glands were defined with the aim to study the patterns of variability of morphophysiological indexes. All data were subjected to statistical analysis to obtain information on the variability of those parameters in different intrapopulation groups. In some species there were analyzed the age-related and seasonal variability of morphophysiological indicators in different intrapopulation groups, and also the interspecific variability of these parameters in order to study the effect of the environmental factors on the organism's physiology.
\end{abstract}

Key words: Muroidea, Transcarpathia, abundance, sex and age structure, morphophysiology.

Гризуни надродини Muroidea рівнинного Закарпаття: стан популяцій та морфофізіологія. - Баркасі, 3. - Праця присвячена результатам досліджень рівнинних популяцій мишуватих гризунів на Закарпатті. Польові роботи зі збору матеріалів проведено у трьох типових біотопах у межах Берегівського району. У праці подано відомості про найбільш поширені види мишуватих гризунів в межах району як типового рівнинного регіону Закарпаття. Проаналізовано відносну чисельність цих видів, а також тенденції у статево-віковій структурі популяцій. Для дослідження вікової і статевої мінливості морфологічних ознак проведено проміри довжини тіла, хвоста, стопи і вушної раковини. 3 метою вивчення мінливості морфофізіологічних показників тіла визначено відносну масу фізіологічно важливих органів, зокрема серця, печінки, нирок і наднирників. Всі дані були статистично оброблені з метою аналізу мінливості цих параметрів у різних внутрішньопопуляційних груп, а також міжвидової мінливості цих показників 3 метою вивчення впливу факторів середовища на фізіологію організму.

Ключові слова: Muroidea, Закарпаття, чисельність, статево-вікова структура, морфофізіологія.

\section{Introduction}

The Ukrainian Carpathians are located in the northeastern part of the Carpathian Basin. Systematic research of the fauna of this part of the Carpathian Mountains and adjacent lowland areas started in the middle of the $20^{\text {th }}$ century (Янушевич, 1947; Колюшев, 1953, 1956, 1957; Татаринов, 1956; Турянин, 1959; Корчинский, 1975, 1980, 1988). In those times, zoologists concentrated their attention on issues of the species composition and distribution in different types of habitats. To the investigation of rodents within the region has been given a leading role from the very beginning - from 1947 to 1959 there were published over 50 papers concerning different aspects (e.g. distribution, population density, ecology, systematics) of the rodent fauna's biology (Корчинский, 1988). From the 1970s works have been appeared on research of small mammals' ecology (particularly, rodents and bats) using the method of morphophysiological indicators (Крочко, 1970; Корчинський 1997, 1999, 2003). However, during the last decade such investigations were not performed. 
The present research was carried out in three types of biotopes within the Berehove raion, which is located in the SW part of the Transcarpathian region (W Ukraine). The mentioned area is opened and low-lying, however in the NW is quiet hilly. Territories covered by woodlands are not too much (Географія, 2014).

The rodent fauna of the researched area during the last decade was studied insufficiently. This is one of the main reasons to investigate the quantitative and qualitative composition of muroid populations in the territory, alongside with the variability of morphological and morphophysiological parameters as indicators of changes in habitats.

\section{Material and methods}

The material used in the analysis was collected from 2012 until 2014 in different types of biotopes within the Berehove raion.

The Berehove raion is a lowland area of Transcarpathia. Its territory is 65437000 ha. The average height above the sea level is $115-130 \mathrm{~m}$. The structure of land resources is the following: agricultural lands (45961000 ha, including 33945000 ha of arable lands and 9284000 ha of woodlands), built-up lands (4 $233000 \mathrm{ha}$ ), lands of water resources (2 $890000 \mathrm{ha}$ ) and other kinds of lands (Паспорт, 2014).

The sample contains 99 specimens of six species of the Muroidea superfamily (tab. 1). The systematics and species nomenclature agreed with the "Field key to small mammals of Ukraine" (Загороднюк, 2002) and the "Тахоnomy and nomenclature of mammals of Ukraine" (Загороднюк, Смельянов, 2012).

The animals were collected by Hero traps, according to the method of small mammals account on trap-lines (Межжерин и др., 1991; Константинов и др., 2000; Загороднюк, 2002; Нумеров и др., 2010). The obtained materials were processed according to the method of morphophysiological indicators (Шварц и др., 1968). The species' relative abundance assessed in the number of individuals per 100 trap-days separately for all types of investigated biotopes. The age of mice was determined by the degree of the tooth crown surface's wear, and the age of voles was determined by the degree of development of the molar teeth's root (Варшавский, 1948; Тупикова, 1964). In some cases, we also paid attention to the body and tail length as well as the skull's sculptural relief. Four age groups were distinguished (age is in months): I $-1-2$, II $-2-4$, III $-4-8$, IV -8 and more.

\section{Results and their discussion}

\section{Relative abundance, sex and age structure of populations of some muroid species}

There are 19 species of the Muroidea superfamily in the region of the Ukrainian Carpathians (Загороднюк та ін., 1997). We found six species of this superfamily in the examined biotopes. As it turned out, specimens of $A$. agrarius have the largest fraction in the sample, which is a typical lowland species in the Ukrainian Carpathians area. It is also a common species of fields and shrubs. There are three subdominant species: S. tauricus and M. glareolus in the wooded areas, and M. arvalis on the fields (fig. 1).

The counts of the relative abundance showed that in summertime the most abundant species are the following: A. agrarius (14 examples/100 tap-days) and M. arvalis ( $8 \mathrm{ex} / 100$ tap-days) on the fields, A. agrarius and M. glareolus (5.5 ex/100 tap-days for each) in shrubs. As it turned out, the most active species in the cold period of year in the region is the striped filed mouse, A. agrarius (10 ex/100 tap-days). In addition, the low abundance of the species in indistinctive for them biotopes was also confirmed, for instance, the low abundance of the stripped field mouse in forests and also the abundance of the yellow-necked wood mouse on fields (1 ex/100 tap-days for each).

Based on the available data, we tried to identify the trends in the populations' sex and age structure in some species. Thus, the populations of mice are characterized by a tendency of predomination the examples of the III and IV age groups that are actively reproducing (fig. 2-3). In the S. tauricus population, we observed a tendency of predomination the pubescent males, although the 
number of females is larger among the older examples (IV age group). Due to larger number of specimens of $A$. agrarius we can judge about the population structure of this species with more certainty. Thus, almost the same proportion of different sex individuals characterizes it. However, there is a slight predominance of males in all age groups (fig. 3).

In the M. glareolus population we can observe a tendency to depression at current stage of the population dynamics (fig. 4). The small number of individuals taking part in reproduction is an evidence for this conclusion. Furthermore, there were not found females with traces of pregnancy: neither uterine spots nor visible embryos. On the other hand, the population is characterized by predomination of juvenile males (II age group), although they do not participate in the population's reproduction yet (according to testicles and seminal vesicles sizes).

Judgments about the population's structure of M. arvalis are less reliable because of the small number of collected examples. Despite this, we have general ideas about the state of this species population - it is characterized by a tendency of female's predominance in all age groups. Uterine spots were found in most of the examples that proves their participation in reproduction (fig. 5). There are fractions of males only in the I and II age groups.

\section{Morphophysiological indexes of some muroid species}

During the second half of the $20^{\text {th }}$ century the method of the morphophysiological indicators was widely used in investigations concerning the ecology of vertebrate populations. The method implies the use of a set of indirect signs that allows estimating the physiological peculiarities of the animals in field in the process of their vital functions' seasonal cyclicity. By using a certain set of indicators it is possible to fix the very first stages of violations of the normal course of intrapopulation processes (Шварц и др., 1968).

Table 1. Number of collected species from the investigated biotopes of the Berehove raion Таблиця 1. Кількість здобутих видів у досліджених біотопах Берегівського району

\begin{tabular}{|c|c|c|c|c|c|c|c|c|}
\hline \multirow{3}{*}{ Species } & \multicolumn{6}{|c|}{ Biotope } & \multirow{2}{*}{\multicolumn{2}{|c|}{ Total }} \\
\hline & \multicolumn{2}{|c|}{ Shrubs } & \multicolumn{2}{|c|}{ Oak forest } & \multicolumn{2}{|c|}{ Field } & & \\
\hline & $\mathrm{n}$ & $\%$ & $\mathrm{n}$ & $\%$ & $\mathrm{n}$ & $\%$ & $\mathrm{n}$ & $\%$ \\
\hline Apodemus agrarius (Pallas, 1771) & 21 & 47 & 1 & 12 & 28 & 61 & 50 & 51 \\
\hline Sylvaemus tauricus (Pallas, 1811) & 7 & 15 & 7 & 88 & 2 & 4 & 16 & 16 \\
\hline Myodes glareolus (Schreber, 1780) & 16 & 36 & - & - & - & - & 16 & 16 \\
\hline Microtus arvalis (Pallas, 1779) & - & - & - & - & 13 & 28 & 13 & 13 \\
\hline Terricola subterraneus (Selys-Longchamps, 1836) & 1 & 2 & - & - & - & - & 1 & 1 \\
\hline Mus musculus Linnaeus, 1758 & - & - & - & - & 3 & 7 & 3 & 3 \\
\hline Number of specimens, $\mathrm{N}$ & \multicolumn{2}{|c|}{45} & \multicolumn{2}{|c|}{8} & \multicolumn{2}{|c|}{46} & \multicolumn{2}{|c|}{99} \\
\hline Number of species, $\mathrm{S}$ & \multicolumn{2}{|c|}{4} & \multicolumn{2}{|c|}{2} & \multicolumn{2}{|c|}{4} & \multicolumn{2}{|c|}{6} \\
\hline Number of trap-days & \multicolumn{2}{|c|}{400} & \multicolumn{2}{|c|}{100} & \multicolumn{2}{|c|}{400} & \multicolumn{2}{|c|}{900} \\
\hline
\end{tabular}

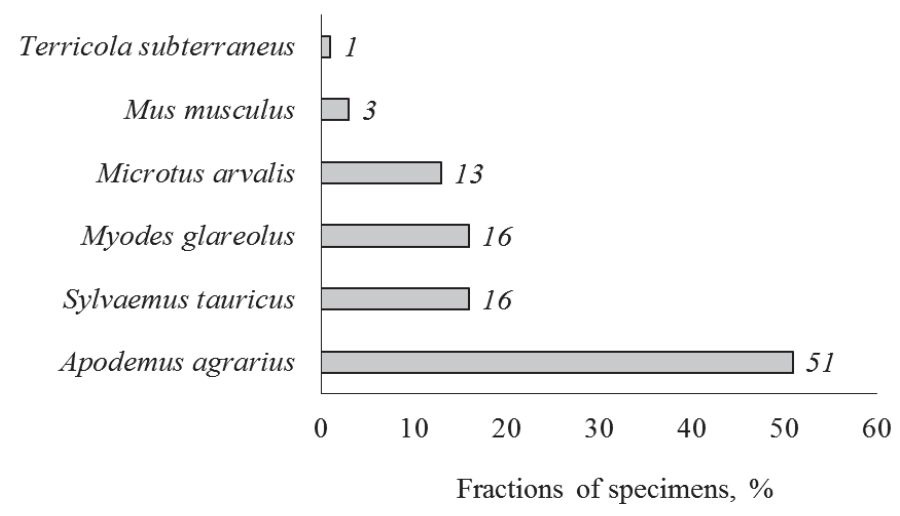

Fig. 1. Fractions of different muroid species in the sample.

Рис. 1. Частки різних видів мишуватих у вибірці. 


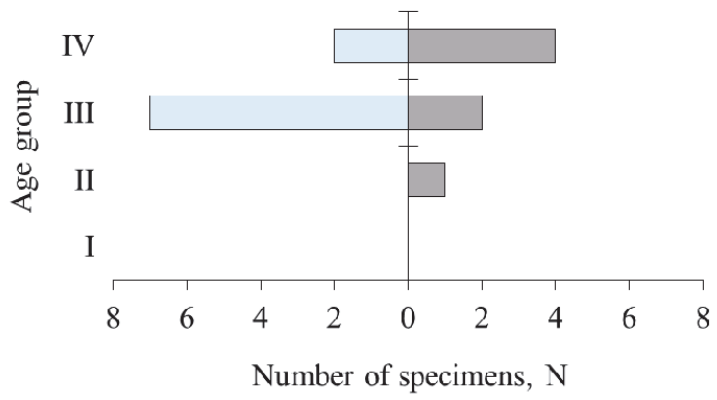

Fig. 2. Sex and age structure of the Sylvaemus tauricus population $(\mathrm{M} \mid \mathrm{F})$.

Рис. 2. Статево-вікова структура популяції Sylvaemus tauricus.

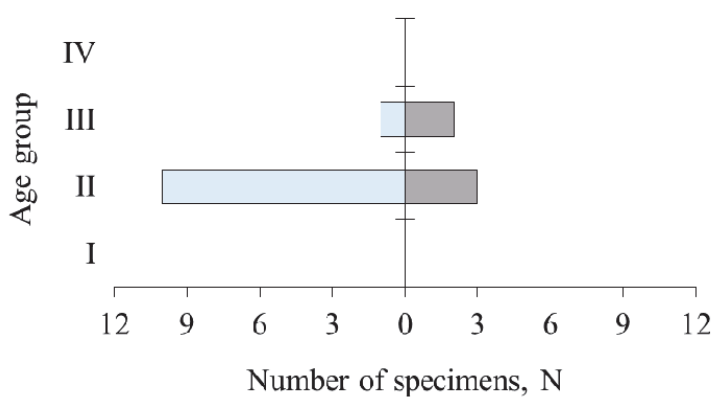

Fig. 4. Sex and age structure of the Myodes glareolus population $(\mathrm{M} \mid \mathrm{F})$.

Рис. 4. Статево-вікова структура популяції Myodes glareolus.

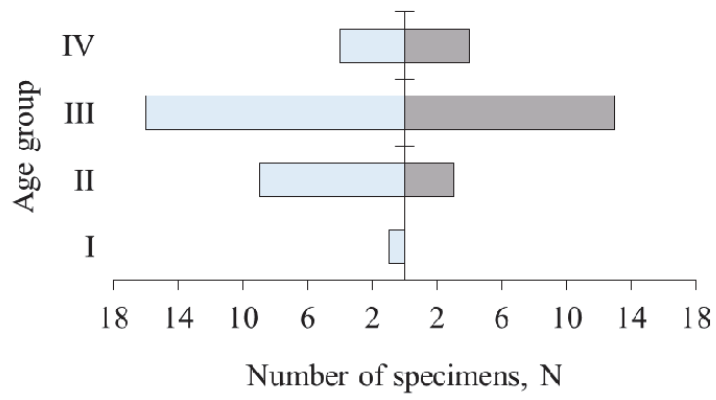

Fig. 3. Sex and age structure of the Apodemus agrarius population $(\mathrm{M} \mid \mathrm{F})$.

Рис. 3. Статево-вікова структура популяції Apodemus agrarius.

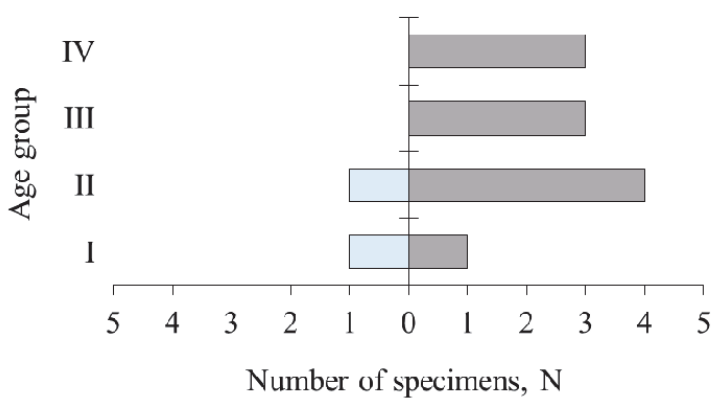

Fig. 5. Sex and age structure of the Microtus arvalis population $(\mathrm{M} \mid \mathrm{F})$.

Рис. 5. Статево-вікова структура популяції Microtus arvalis.

In the process of studying the muroid populations the following parameters were used: linear body dimensions such as the body length $(\mathrm{L})$, tale length $(\mathrm{Ca})$, foot length $(\mathrm{Pl})$ and auricle length $(\mathrm{Au})$; relative weight of the body and internal organs such as heart $(\mathrm{Cr})$, liver $(\mathrm{Hp})$, kidneys $(\mathrm{Rn})$ and adrenal glands (GSr) (tab. 2-3). Note that the data of samples infected by macroparasites were not taken into the statistics.

The analysis of morphological parameters of the collected specimens proves that the body weight grows with the age in all species. The value of this indicator decreases in the cold period of year due to exhaustion of the organism caused by consumption of the body energetic reserves. Such exterior parameters as body length (L) and tail length $(\mathrm{Ca})$ undergo to major changes with the age, but the value of the foot length $(\mathrm{Pl})$ and auricle length ( $\mathrm{Au}$ ) are less variable, so they can be used in systematics.

Investigation of seas onal changes of the interior parameters shows that in wintertime in all examined species the indexes of the liver and kidneys are lower, but the indexes of the heart and adrenal glands are higher than of the same population samples caught during summer. Obviously, such character of seasonal changes of these organs' indexes has two reasons. On the first hand, it is the shortage of food, which means the impossibility of storing proper amount of nutrients (rather in form of glycogen) and slowing down the metabolism as a result. On the other hand, it is the organism's high energetic tension and active searching for food that also leads to the reserves' mobilization (Шварц и др., 1968).

In case of specimens of summertime samples from the populations, they are characterized by higher indexes of heart and kidneys and lower indexes of adrenal glands in the younger age groups. Such pattern of age-related changes of those indexes associated with the high energetic tension of 
breeding animals. Because of this, in the case of adrenal glands the "rule of ranks" is not maintained ${ }^{1}$. Besides, it is important to mention that among the examined species the yellow-necked wood mouse (S. tauricus) has the highest values of GSr index, moreover, it is discovered that the relative weight of the adrenal glands is always higher in males, which is apparently due to their higher aggressiveness.

The indexes of liver vary similarly, which are usually higher in lacting and pregnant females. This is due to storing a significant amount of nutrients as glycogen, which leads to an increase in the liver's weight.

Statistically significant interspecific differences $(t \geq 2)$ among the same-age and samesex groups of the examined rodent species were found on most exterior parameters. As an example, $M$. arvalis significantly differs from $A$. agrarius on the following parameters: tail length, $\mathrm{Ca}(\mathrm{t}=15)$ and foot length, $\mathrm{Pl}(\mathrm{t}=2.9)$; from $S$. tauricus the species differs on three types of parameters: tail length, $\mathrm{Ca}(\mathrm{t}=8.7)$, foot length, $\mathrm{Pl}(\mathrm{t}=11.4)$ and auricle length, $\mathrm{Au}(\mathrm{t}=8.6)$.

Table 2. Intrapopulation and interspecific variability of linear body sizes of different rodent species from the Berehove raion of Transcarpathia (individual value / $\mathrm{X} \pm \sigma / \min -\max$ )

Таблиця 2. Внутрішньопопуляційна та міжвидова мінливість лінійних розмірів тіла у різних видів гризунів 3 Берегівського району Закарпаття (індивідуальне значення / $\mathrm{X} \pm \sigma / \min -\max )$

\begin{tabular}{|c|c|c|c|c|c|c|c|}
\hline \multirow{2}{*}{ Species } & \multirow{2}{*}{$\begin{array}{l}\text { Age } \\
\text { group }\end{array}$} & \multirow{2}{*}{ N, Sex } & \multirow{2}{*}{$\begin{array}{c}\text { Body weight, } \\
g \\
\end{array}$} & \multicolumn{4}{|c|}{ Exterior parameters } \\
\hline & & & & $\mathrm{L}, m m$ & $\mathrm{Ca}, m m$ & $\mathrm{Pl}, \mathrm{mm}$ & $\mathrm{Au}, m m$ \\
\hline & Octobe & (2012) & & & & & \\
\hline \multirow[t]{4}{*}{ M. arvalis } & I & $1 \mathrm{~F}$ & 9.2 & 65.0 & 21.0 & 17.0 & 9.0 \\
\hline & II & $3 F+1 M$ & $15.8 \pm 3.8$ & $79.3 \pm 4.6$ & $25.8 \pm 4.7$ & $14.8 \pm 0.4$ & $9.8 \pm 0.4$ \\
\hline & III & $2 \mathrm{~F}$ & $29.1-31.1$ & $102.0-107.0$ & $39.0-43.0$ & $16.0-18.0$ & 12.0 \\
\hline & \multicolumn{7}{|c|}{ February $(2013,2014)$} \\
\hline S. tauricus & IV & $1 \mathrm{~F}+2 \mathrm{M}$ & $38.9 \pm 10.9$ & $105.7 \pm 11.9$ & $103.0 \pm 10.7$ & $24.3 \pm 1.9$ & $19.3 \pm 1.3$ \\
\hline A. agrarius & III & $2 \mathrm{~F}+8 \mathrm{M}$ & $20.3 \pm 3.1$ & $86.1 \pm 7.6$ & $70.0 \pm 5.7$ & $19.0 \pm 1.8$ & $12.1 \pm 1.4$ \\
\hline \multirow[t]{2}{*}{ M. glareolus } & II & $4 \mathrm{M}$ & $15.6 \pm 0.5$ & $84.3 \pm 4.3$ & $34.5 \pm 0.5$ & $17.3 \pm 2.2$ & $13.0 \pm 1.2$ \\
\hline & \multicolumn{7}{|c|}{ July-August $(2013,2014)$} \\
\hline S. tauricus & $\begin{array}{l}\text { II } \\
\text { III } \\
\text { IV }\end{array}$ & $\begin{array}{c}1 \mathrm{~F} \\
1 \mathrm{~F}+6 \mathrm{M} \\
4 \mathrm{~F}\end{array}$ & $\begin{array}{c}19.3 \\
25.5 \pm 4.2 \\
37.9 \pm 6.4\end{array}$ & $\begin{array}{c}87.0 \\
94.7 \pm 4.9 \\
100.5 \pm 7.4\end{array}$ & $\begin{array}{c}81.0 \\
91.4 \pm 4.5 \\
95.3 \pm 6.3\end{array}$ & $\begin{array}{c}20.0 \\
24.7 \pm 1.5 \\
25.0 \pm 0.7\end{array}$ & $\begin{array}{c}15.0 \\
15.6 \pm 1.8 \\
19.0 \pm 0.7\end{array}$ \\
\hline \multirow[t]{7}{*}{ A. agrarius } & I & $1 \mathrm{M}$ & 10.5 & 71.0 & 51.0 & 16.0 & 11.0 \\
\hline & II & $3 \mathrm{~F}$ & $15.6 \pm 1.2$ & $83.7 \pm 1.2$ & $64.7 \pm 2.4$ & $16.7 \pm 0.9$ & $10.3 \pm 0.9$ \\
\hline & II & $9 \mathrm{M}$ & $15.5 \pm 1.3$ & $81.7 \pm 2.7$ & $64.7 \pm 3.1$ & $18.2 \pm 1.1$ & $11.0 \pm 0.5$ \\
\hline & III & $11 \mathrm{~F}$ & $23.7 \pm 4.1$ & $91.4 \pm 4.3$ & $69.9 \pm 4.1$ & $18.3 \pm 1.1$ & $11.8 \pm 0.7$ \\
\hline & III & $8 \mathrm{M}$ & $21.8 \pm 3.4$ & $92.1 \pm 6.0$ & $69.1 \pm 2.8$ & $19.3 \pm 0.4$ & $11.6 \pm 0.9$ \\
\hline & IV & $4 \mathrm{~F}$ & $30.5 \pm 1.6$ & $100.5 \pm 3.3$ & $75.0 \pm 1.9$ & $19.0 \pm 0.7$ & $13.0 \pm 0.7$ \\
\hline & IV & $4 \mathrm{M}$ & $29.0 \pm 1.5$ & $105.3 \pm 2.5$ & $74.3 \pm 3.0$ & $19.0 \pm 0.7$ & $12.8 \pm 0.4$ \\
\hline \multirow[t]{3}{*}{ M. glareolus } & II & $3 \mathrm{~F}$ & $18.2 \pm 4.05$ & $85.3 \pm 7.8$ & $37.0 \pm 2.8$ & $16.3 \pm 0.5$ & $12.0 \pm 1.4$ \\
\hline & II & $5 \mathrm{M}$ & $14.1 \pm 0.6$ & $83.8 \pm 4.2$ & $34.4 \pm 1.0$ & $16.2 \pm 0.4$ & $10.6 \pm 0.8$ \\
\hline & III & $1 \mathrm{~F}+1 \mathrm{M}$ & $20.3-26.1$ & $95.0-102.0$ & 43.0 & $16.0-17.0$ & 12.0 \\
\hline \multirow[t]{4}{*}{ M. arvalis } & I & $1 \mathrm{M}$ & 11.8 & 67.0 & 24.0 & 15.0 & 8.0 \\
\hline & II & $1 \mathrm{~F}$ & 22.5 & 92.0 & 31.0 & 16.0 & 10.0 \\
\hline & III & $1 \mathrm{~F}$ & 26.3 & 101.0 & 33.0 & 15.0 & 12.0 \\
\hline & IV & $2 \mathrm{~F}$ & $34.4-36.4$ & $111.0-114.0$ & $37.0-40.0$ & 17.0 & 13.0 \\
\hline
\end{tabular}

${ }^{1}$ According to the "rule of ranks," the smaller is the relative body weight of an animal the higher are the indexes of main internal organs. 
Table 3. Intrapopulation and interspecific variability of morpho-physiological parameters of different rodent species from the Berehove raion of Transcarpathia (individual value / $\mathrm{X} \pm \sigma / \min -\max$ )

Таблиця 3. Внутрішньопопуляційна та міжвидова мінливість морфо-фізіологічних показників у різних видів гризунів з Берегівського району Закарпаття (індивідуальне значення / X $\pm \sigma / \min -\max$ )

\begin{tabular}{|c|c|c|c|c|c|c|c|}
\hline \multirow{2}{*}{ Species } & \multirow{2}{*}{$\begin{array}{l}\text { Age } \\
\text { group }\end{array}$} & \multirow{2}{*}{ N, Sex } & \multirow{2}{*}{$\begin{array}{c}\text { Body } \\
\text { weight, } g\end{array}$} & \multicolumn{4}{|c|}{ Interior parameters } \\
\hline & & & & $\mathrm{Cr}, \%$ & Нp, \%o & Rn, \%o & GSr, $\% o$ \\
\hline & \multicolumn{7}{|c|}{ October (2012) } \\
\hline \multirow[t]{4}{*}{ M. arvalis } & I & $1 \mathrm{~F}$ & 9.2 & 6.96 & 40.98 & 13.70 & 0.22 \\
\hline & II & $3 F+1 M$ & $15.6 \pm 3.8$ & $5.59 \pm 1.19$ & $50.52 \pm 9.63$ & $10.39 \pm 1.54$ & $0.46 \pm 0.14$ \\
\hline & III & $2 \mathrm{~F}$ & $29.1-31.1$ & $4.51-4.86$ & $49.16-52.45$ & $9.54-12.70$ & $0.61-0.99$ \\
\hline & \multicolumn{7}{|c|}{ February $(2013,2014)$} \\
\hline S. tauricus & IV & $1 \mathrm{~F}+2 \mathrm{M}$ & $38.9 \pm 10.9$ & $5.89 \pm 0.79$ & $35.67 \pm 3.37$ & $8.05 \pm 0.67$ & $0.50 \pm 0.32$ \\
\hline A. agrarius & III & $2 \mathrm{~F}+8 \mathrm{M}$ & $20.3 \pm 3.1$ & $6.85 \pm 0.75$ & $50.74 \pm 9.38$ & $10.81 \pm 1.88$ & $0.21 \pm 0.15$ \\
\hline \multirow[t]{2}{*}{ M. glareolus } & II & $4 \mathrm{M}$ & $15.6 \pm 0.5$ & $7.3 \pm 1.4$ & $45.48 \pm 4.4$ & $11.07 \pm 2.4$ & $0.16 \pm 0.04$ \\
\hline & \multicolumn{7}{|c|}{ July-August $(2013,2014)$} \\
\hline \multirow[t]{3}{*}{ S. tauricus } & II & $1 \mathrm{~F}$ & 19.3 & 8.57 & 105.30 & 18.70 & 0.42 \\
\hline & III & $1 \mathrm{~F}+6 \mathrm{M}$ & $25.5 \pm 4.2$ & $6.18 \pm 0.98$ & $54.52 \pm 6.07$ & $11.89 \pm 1.79$ & $0.30 \pm 0.09$ \\
\hline & IV & $4 \mathrm{~F}$ & $37.9 \pm 6.4$ & $5.09 \pm 0.36$ & $53.03 \pm 9.87$ & $10.56 \pm 1.65$ & $0.23 \pm 0.09$ \\
\hline \multirow[t]{7}{*}{ A.agrarius } & I & $1 \mathrm{M}$ & 10.5 & 12.49 & 60.82 & 18.30 & 0.57 \\
\hline & II & $3 \mathrm{~F}$ & $15.6 \pm 1.2$ & $8.04 \pm 0.68$ & $47.54 \pm 8.23$ & $14.35 \pm 0.47$ & $0.30 \pm 0.04$ \\
\hline & II & $9 \mathrm{M}$ & $15.5 \pm 1.3$ & $7.99 \pm 0.93$ & $53.07 \pm 10.07$ & $15.64 \pm 1.42$ & $0.36 \pm 0.09$ \\
\hline & III & $11 \mathrm{~F}$ & $23.7 \pm 4.1$ & $7.23 \pm 1.00$ & $70.34 \pm 9.73$ & $14.45 \pm 2.57$ & $0.45 \pm 0.19$ \\
\hline & III & $8 \mathrm{M}$ & $21.8 \pm 3.4$ & $7.42 \pm 1.12$ & $58.86 \pm 9.95$ & $13.78 \pm 1.66$ & $0.36 \pm 0.09$ \\
\hline & IV & $4 \mathrm{~F}$ & $30.5 \pm 1.6$ & $6.53 \pm 1.04$ & $81.00 \pm 18.68$ & $15.11 \pm 2.16$ & $0.43 \pm 0.09$ \\
\hline & IV & $4 \mathrm{M}$ & $29.0 \pm 1.5$ & $7.29 \pm 0.26$ & $65.84 \pm 4.80$ & $14.36 \pm 2.38$ & $0.46 \pm 0.07$ \\
\hline \multirow[t]{3}{*}{ M. glareolus } & II & $3 \mathrm{~F}$ & $18.2 \pm 4.1$ & $6.54 \pm 1.06$ & $50.74 \pm 2.63$ & $12.39 \pm 2.00$ & $0.29 \pm 0.18$ \\
\hline & II & $5 \mathrm{M}$ & $14.1 \pm 0.6$ & $6.77 \pm 0.45$ & $49.07 \pm 3.59$ & $12.55 \pm 1.81$ & $0.16 \pm 0.03$ \\
\hline & III & $1 \mathrm{~F}+1 \mathrm{M}$ & $20.3-26.1$ & $5.66-6.96$ & $49.88-49.89$ & $12.85-12.89$ & $0.15-0.27$ \\
\hline \multirow[t]{4}{*}{ M. arvalis } & I & $1 \mathrm{M}$ & 11.8 & 6.33 & 61.57 & 15.79 & 0.34 \\
\hline & II & $1 \mathrm{~F}$ & 22.5 & 5.51 & 81.13 & 17.67 & 0.53 \\
\hline & III & $1 \mathrm{~F}$ & 26.9 & 4.26 & 63.93 & 12.75 & 0.57 \\
\hline & IV & $2 \mathrm{~F}$ & $34.4-36.4$ & $4.77-5.17$ & $56.81-64.43$ & 12.08 & 0.64 \\
\hline
\end{tabular}

The striped field mouse $A$. agrarius significantly differs from the yellow-necked wood mouse S. tauricus also on three exterior parameters: $\mathrm{Ca}(\mathrm{t}=3.1), \mathrm{Pl}(\mathrm{t}=6)$ and $\mathrm{Au}(\mathrm{t}=6)$.

According to the data we have, the bank vole $M$. glareolus differs from $A$. agrarius only on the tail length $\mathrm{Ca}(\mathrm{t}=9.3)$, but from $S$. tauricus the species significantly differs on three exterior parameters such as $\mathrm{Ca}(\mathrm{t}=10.8), \mathrm{Pl}(\mathrm{t}=5.2)$ and $\mathrm{Au}(\mathrm{t}=2)$.

Considering the statistically significant differences among the species on most of exterior parameters those morphological features can be used in taxonomy and during the species identification as well.

Significant interspecific differences on the internal organs' indexes were revealed only on the index of adrenal glands (GSr) in two cases. Thus, on the index of this organ the common vole $M$. arvalis differs from the yellow-necked wood mouse $S$. tauricus $(\mathrm{t}=3.7)$ and the bank vole M. glareolus differs from the striped field mouse A. agrarius $(\mathrm{t}=2)$. This phenomenon is obviously due to different levels of metabolic processes and higher activity and aggressiveness of mice (the latter can be proved by higher indexes of heart (Cr) in mice). 


\section{Conclusions}

Among the muroid rodents, according to our data, on the lowland part of Transcarpathia the dominant species is the striped field mouse A. agrarius. Such species as M. arvalis, S. tauricus and M. glareolus are subdominants. Obviously, such distribution related to the features of landscapes and habitat types.

The analysis of the sex and age structure of populations of the most abundant species showed the tendency of predomination of mature individuals, especially males in mice populations. Mature females are the most numerous in the common vole's population. The bank vole population at the current stage of its dynamics is in depressive state.

The investigation of morphological and morphophysiological indicators showed that such linear body parameters as body length $(\mathrm{L})$ and tail length $(\mathrm{Ca})$ essentially change with the age, although the foot length $(\mathrm{Pl})$ and the auricle length $(\mathrm{Au})$ are less variable. The indexes of the liver $(\mathrm{Hp})$ and kidneys (Rn) are clearly lower in winter, which is related to peculiarities of the metabolism in the cold period of the year, namely with running out the reserves of nutrients and slowing down the metabolic processes. The indexes of the heart $(\mathrm{Cr})$ and kidneys $(\mathrm{Rn})$ in summertime samples are higher in the young age groups, but the indexes of the adrenal glands (GSr) are lower. The latter is related to higher activity and higher level of metabolism in young animals. The index of the adrenal glands (Gsr) are usually higher in mature individuals that take part in reproduction.

Significant interspecific differences were revealed on most of the linear parameters, which is important for the taxonomy and the species identifying as well.

\section{References}

Варшавский, С. Н., Крылова, К. Т. Основные принципы определения возраста мышевидных грызунов // Фауна и экология грызунов. - 1948. - Том 3. - С. 179-189.

[Varshavsky, S. N., Krylova, K. T. Basic principles of the mouse-like rodents age determining // Fauna and Ecology of Rodents. — 1948. — Vol. 3. — P. 179-189. (in Rus.).]

Географія Берегівського району, Інтернет-ресурс. — http://goo.gl/mlQcgi

[Geography of the Berehove Raion. Web source. — http://goo.gl/mlQcgi (in Ukr.).]

Загороднюк, I. В. Польовий визначник дрібних ссавців України. - Київ, 2002. - Праці Теріологічної Школи, Вип. 5. - $60 \mathrm{c.}$

[Zagorodniuk, I. V. Field Key to Small Mammals of Ukraine. - Kyiv, 2002. - Proceedings of the Theriological School, vol. 5. - 60 p. (in Ukr.).]

Загороднюк, I., Покиньчереда, В, Киселюк, О., Довганич, Я. Теріофауна Карпатського біосферного заповідника. — Київ : Ін-т зоол. НАНУ, 1997. — 60 с. — (Дод. 5 до "Вестник зоологии").

[Zagorodniuk, I., Pokynchereda, V., Kyselyuk, O., Dovganych, Ya. Theriofauna of the Carpathian Biosphere Reserve // Vestnik Zoologii. - 1997. - Supplement N 5. - 60 p. (in Ukr.).

Загороднюк, I. В., Смельянов, I. Г. Таксономія і номенклатура ссавців України // Вісн. Націон. науковоприрод. музею. - 2012. - № 10. - С. 5-30.

[Zagorodniuk, I. V., Emelyanov, I. G. Taxonomy and nomenclature of mammals of Ukraine // Proceedings of the National Museum of Natural History. - 2012. - Vol. 10. - P. 5-30. (in Ukr.).]

Колюшев, И. И. Краткий очерк фауны грызунов Закарпатской области // Научн. зап. Ужгород. ун-та. - Ужгород, 1953. - Т. 21. - С. 29-30.

[Koliushev, I. I. A brief sketch of the rodent fauna of Transcarpathia // Sci. bull. Uzhhorod Univ. - 1953. - Vol. 8. P. 143-189. (in Rus.).]

Колюшев, И. И. Итоги изучения позвоночных животных за 10 лет (1945-1955) // Научн. зап. Ужгород. унта. - Ужгород, 1956. - Т. 21. - С. 31-40.

[Koliushev, I. I. Results of studying of vertebrate animals for 10 years (1945-1955) // Sci. bull. Uzhhorod Univ. — 1956. Vol. 21. - P. 31-40. (in Rus.).]

Колюшев, И. И. Фауна позвоночных животных Советских Карпат // Научн. зап. Ужгород. ун-та. Сер. биол. Ужгород, 1957. — № 1. - С. 29-30.

[Koliushev, I. I. The fauna of vertebrate animals of the Soviet Carpathians // Sci. Bull. Uzhhorod Univ. Ser. Biol. — 1957. — Vol. 1. - P. 29-30. (in Rus.).]

Константинов, В. М., Бутьев, В. Т., Дерим-Оглу, Е. Н. и др. Позвоночные животные и наблюдения за ними в природе. - Москва : Изд. центр «Академия», 2000. — 200 с.

[Konstantinov, V. M., Butiev, V. T., Derim-Oglu, Ye. N. et al. Vertebrate Animals and Their Observation in the Nature. Moscow : Academia Publishing Centre, 2000. — 200 p. (in Rus.).] 
Корчинский, A. В. Изменение морфофизиологических показателей у желтогорлой мыши в связи с вертикальной зональностью // Актуальные вопросы зоогеографии. VI Всесоюзная зоогеографическая конференция (тезисы докладов). — Кишинев : Изд-во «Штиинца», 1975. — С. 122-123.

[Korchynsky, A. V. Changes of the morphophysiological parameters of the yellow-necked wood mouse due to vertical zoning // Actual issues of zoogeography. VI All-Union Conference on Zoogeography (collection of abstracts). — Kishinev : Shtintsa Publishing, 1975. - P. 122-123. (in Rus.).]

Корчинский, А. В. Жолтогорлая и полевая мыши Закарпатья : Автореф. канд. дис. - Киев, 1980. - 21 с. [Korchynsky, A. V. The Yellow-Necked Wood Mouse and Striped Field Mouse in Transcarpathia : Synopsis of PhD thesis. Kyiv, 1980. - 20 p. (in Rus.).]

Корчинский, А. В. Грызуны Украинских Карпат (Итоги исследования) // Вопросы охраны и рационального использования растительного и животного мира Украинских Карпат. - Ужгород, 1988. - С. $156-173$. [Korchynsky, A. V. The rodents of the Ukrainian Carpathians (research results) // Issues of the Ukrainian Carpathians flora and fauna protection and rational use. - Uzhhorod, 1988. - P. 156-173. (in Rus.).]

Корчинський, О. В. Внутрішньо- і міжпопуляційна мінливість морфологічних і морфофізіологічних показників у жовтогорлої миші Закарпаття. Матеріали міжнародного регіонального семінару «Охорона довкілля: сучасні дослідження в екології і мікробіології». - Ужгород, 1997 - С. 238-243.

[Korchynsky, $O . V$. Intro- and interpopulation variability of morphological and morpho-physiological indexes in the yellownecked wood mouse of Transcarpathia // Proceedings of the international regional seminar "Environment protection: modern research in ecology and microbiology." — Uzhhorod, 1997. — P. 238-243. (in Ukr.).]

Корчинський, О. В. Внутрішньопопуляційна та міжвидова мінливість морфо-фізіологічних ознак у гризунів Закарпаття // Наук. вісник Ужгор. держ. ун-ту. Серія Біологія. — 1999. — Вип. 6. - С. 79-86.

[Korchynsky, $O . V$. Intrapopulation and interspecific variability of morpho-physiological features in rodents of Transcarpathia // Sci. Bull. Uzhhorod Univ. Ser Biol. — 1999. — Vol. 6. — P. 79-86. (in Ukr.).]

Корчинський, О. В. Особливості вікової структури популяцій фонових видів дрібних гризунів у лісових екосистемах Закарпаття на різних фазах динаміки чисельності // Наук. вісн. Ужгород. ун-ту. Сер. біол. 2003. - Вип. 13. - С. 59-61.

[Korchynsky, O. V. Features of the age structure of abundant species populations in wood ecosystems of Transcarpathia at different phases of the population dynamics // Sci. bull. Uzhhorod Univ. Ser. Biol. — 2003. — Vol. 13. — P. 59-61. (in Ukr.).]

Крочко, Ю. И. Морфологические и эколого-физиологические особенности популяций большой ночницы и обыкновенного длиннокрыла Закарпатской области. Дис. ... канд. биол. наук. — Киев: Ин-т зоологии АНУ, $1970-178 \mathrm{c}$.

[Krochko, Yu. M. Morphological and Eco-Physiological Features of the Populations of Greater Mouse-Eared Bat and Common Bent-Wing Bat in Transcarpathia : Synopsis of PhD thesis. — Kyiv : Institute of zoology of ASU, 1970. — 178 p. (in Rus.).]

Межжерин, В. А., Емельянов, И. Г., Михалевич, О. А. Комплексные подходи в изучении популяций мелких млекопитающих. - Київ : Наукова думка, 1991. - 204 с.

[Mezhzherin, V. A., Yemelianov, I. G., Michalevych, O. A. Complex Approaches in Studying the Small Mammals Populations. — Kyiv : Naukova Dumka Publishing, 1991. — 204 p. (in Rus.).]

Нумеров, А. Д., Климов, А. С., Труфанова, Е. И. Полевые исследования наземных позвоночных. - Воронеж, 2010. $-301 \mathrm{c}$.

[Numerov, A. D., Klimov, A. S., Trufanova, Ye. I. Field Investigations of Terrestrial Vertebrates. - Voronezh, 2010. - $301 \mathrm{p}$. (in Rus.).]

Паспорт району / Берегівська районна державна адміністрація. Інтернет-ресурс. — http://goo.gl/fwYTzs [Passport of the Raion. Web source. — http://goo.gl/fwYTzs (in Ukr.).]

Татаринов, К. А. Звірі західних областей України. - Київ, 1956. - 187 с. [Tatarinov, K. A. Mammals of the Western Regions of Ukraine. - Kyiv, 1956 - 187 p. (in Ukr.).]

Тупикова, Н. В. Изучение размножения и возрастного состава популяций мелких млекопитающих // Методы изучения природных очагов болезней человека. - М. : Медицина, 1964. - С. 154-191.

[Tupikova, N. V. Investigation the reproduction and age structure of the populations of small mammals // Research methods of human disease natural foci. — Moscow : Meditsina Publishing, 1964. — P. 154-191. (in Rus.).]

Турянин, И. И. Фауна, хозяйственное и эпидемиологические значение грызунов Закарпатской области // Научн. зап. Ужгород. ун-та. - 1959. - Т. 40. - С. 21-38.

[Turianin, I. I. Fauna and economical and epidemiological importance of rodents in the Transcarpathia region // Sci. bull. Uzhhorod Univ. — 1959. — Vol. 40. - P. 21-38. (in Rus.).]

Швари, С. С., Смирнов, В. С., Добринский, Л. Н. Метод морфофизиологических индикаторов в экологии наземных позвоночных. - Свердловск, 1968. - 386 с.

[Shvarts, S. S., Smirnov, V. S., Dobrinsky, L. N. The Method of Morphophysiological Indicators in the Ecology of Terrestrial Mammals. - Sverdlovsk, 1968. - 386 p. (in Rus.).]

Янушевич, М. Г. Деякі дані про ссавців Закарпатської області // Доп. та повідом. Львів. ун-ту. - Львів, 1947. - Вип. 1. - С. 69-70.

[Yanushevych, M. G. Some data on mammals of the Transcarpathia region // Reports and Notes of Lviv University. 1947. - Vol. 1. - P. 69-70. (in Ukr.).] 